\title{
Variations of hydrosoluble vitamin contents in dairy products during storage
}

\author{
A Diaz Marquina, MT Orzaez Villanueva, \\ MC Matallana Gonzalez
}

\begin{abstract}
Universidad Complutense, Facultad de Farmacia, Nutricion y Bromatologia II:
Bromatologia y Tecnicas Analiticas Farmaceuticas,Ciudad Universitaria, 28040 Madrid, Spain
\end{abstract}

(Received 20 July 1990; accepted 10 May 1991)

\begin{abstract}
Summary - Thiamine and riboflavin contents of 3 dairy products were determined: yoghurt, liquid yoghurt and fresh cheese. These vitamins were analysed in each group according to 3 reference points: i), when the product was distributed to the retailer; ii), after 7 days had elapsed; iii), on the latest consumption date. The results show that these dairy products contribute adequate quantities of thiamine and riboflavin to the diet. With respect to vitamin $B_{1}$, it was observed that the losses occurring during storage are negligible; this is not the case, however, as regards vitamin $B_{2}$.
\end{abstract}

yoghurt / fresh cheese / thiamine / riboflavin

Résumé - Variations de la teneur en vitamines hydrosolubles des produits laitiers durant le stockage. Dans ce travail, nous avons étudié les teneurs en thiamine et riboflavine dans plusieurs produits laitiers : yoghourt naturel, yoghourt liquide et fromage frais. Nous avont fait l'analyse de ces vitamines à trois stades : 1- Le jour de l'arrivée chez le détaillant; 2- après 7 jours de réfrigération; 3le jour de la date limite de vente. D'après les résultats obtenus, nous pouvons dire que les pertes en riboflavine et en thiamine au cours de la conservation sont significatives, les premières étant toutefois plus importantes. Pour ces raisons, nous recommandons de consommer ces produits dans la mesure du possible dès les premiers jours suivant la fabrication.

yoghourt / fromage frais / thiamine / riboflavine

\section{INTRODUCTION}

It is increasingly important to have detailed knowledge of the different foods that we consume each day, in order to help us to establish a balanced diet. For this reason, in this study we have examined the contribution of water-soluble vitamins $B_{1}$ and $B_{2}$ in dairy products, and particularly in natural yoghurts $(Y)$, liquid yoghurts $(L)$ and fresh cheese (Petit Suisse) (P). These products are frequently present in our normal diet; and, particularly in the case of children, from a very early age.

The vitamin value of these products is different from that of milk, particularly in the case of water-soluble vitamins since some of these vitamins are lost when the whey is removed and others are consumed by lactic bacteria.

As indicated above, we were interested in determining the proportion of vita- 
mins contributed by the above-mentioned products in order to establish a balanced optimum intake in our diet. Moreover, these products which are cold-packed and cold-stored are all marked with a latest consumption date which guarantees a period of optimum consumption between the date of manufacture and the latest consumption date. During this period of time, not all the nutrients act in the same manner; the water-soluble vitamins $B_{1}$ and $B_{2}$, which are highly sensitive to different agents, may undergo changes in these dairy products; these changes have also been analysed in this study.

\section{MATERIALS AND METHODS}

\section{Sampling}

Fifty-four samples of dairy products, grouped into 6 batches of natural yoghurts (18 samples in all), 6 of liquid yoghurt ( 18 samples in all) and 6 of Petit Suisse (18 samples in all), were obtained from the shop on 3 different occasions: i), when the product was distributed to the retailer (6 samples); ii), after 7 days ( 6 samples); and iii), on the latest consumption date corresponding to 14 days from the date of purchase (6 samples). The products were stored in a refrigerator at $5^{\circ} \mathrm{C}$ in the dark, remaining in all cases in their original opaque containers, and all the tests were made in duplicate for each of the samples.

\section{Vitamin analysis}

In order to extract these micronutrients, the samples were first subjected to acid and enzyme hydrolysis with acetate buffer and a diastase and papain enzyme solution for $24 \mathrm{~h}$ at 37 ${ }^{\circ} \mathrm{C}$. The samples were then filtered and quantified.

Following this extraction, thiamine content was determined by fluorescence, following prior oxidation to thiocrome in a base medium with potassium ferricyanide (AOAC, 1990).
The riboflavin content was determined by direct fluorescence following oxidation with potassium permanganate (AOAC, 1990).

\section{Statistical analysis}

Data for each dairy product were submitted to variance analysis, the day of storage as studied factor, batch of sample being considered as block.

\section{RESULTS AND DISCUSSION}

Figure 1 represents in graph form the mean values of vitamins $B_{1}$ and $B_{2}$ at the 3 control points established for each of the products.

It may be seen that the vitamin $B_{1}$ content is very similar in all 3 types of product, with figures ranging from $0.040-0.060 \mathrm{mg} /$ $100 \mathrm{~g}$ of product.

The vitamin $B_{2}$ content is higher than the thiamine content in all the samples analysed, with the greatest difference being found in natural yoghurts, with figures



Fig 1. Changes in vitamin $B_{1}$ and $B_{2}$ contents of natural yoghurt, liquid yoghurt and Petit suisse. Variations de la teneur en vitamines hydrosolubles des produits laitiers durant le stockage. 
ranging from $0.198-0.275 \mathrm{mg} / 100 \mathrm{~g}$ of product, followed by liquid yoghurt with similar levels, between $0.180-0.193 \mathrm{mg} /$ $100 \mathrm{~g}$ of product, and finally Petit Suisse, with figures ranging from 0.141 to 0.172 $\mathrm{mg} / 100 \mathrm{~g}$ of product.

The Petit Suisse reflects the largest decrease in vitamin $B_{2}$ content and less in the case of vitamin $\mathrm{B}_{1}$ in comparison with the other products. This is a logical conclusion, since during the manufacturing process of this fresh cheese, part of the whey is removed, with the consequent partial loss of these nutrients.

Following consultation of the bibliography on this subject, we have found only one study (Favier, 1987) in which the thiamine and riboflavin content in natural yoghurts had been quantified, with figures of 0.04 and $0.18 \mathrm{mg} / 100 \mathrm{~g}$ of product, respectively, being obtained. These values are slightly lower than those of 0.056 and $0.277 \mathrm{mg} / 100 \mathrm{~g}$ of product established in our study.

We have also mentioned the Souci tables (1986/1987) and have seen that in the case of the samples of natural yoghurt analysed, with $3.5 \%$ fat content the figures range from $0.03-0.06 \mathrm{mg} \%$ for thiamine and from $0.14-0.24 \mathrm{mg} \%$ for riboflavin. Our values are between those indicated for both micronutrients.

In these same tables, the Petit Suisse, with a $50 \%$ fat content, records levels of $0.047-0.087$ and $0.220-0.410$ for vitamins $B_{1}$ and $B_{2}$ respectively. In this case, our values are slightly lower than the minimum level indicated in all the samples analysed and for both vitamins.
In order to determine whether or not the losses of vitamins $B_{1}$ and $B_{2}$ at 7 and 14 days of refrigerator storage were significant, we statistically processed our data by means of Student Newman-Keuls-Tukey contrast.

\section{CONCLUSIONS}

It is concluded that vitamin $\mathrm{B}_{1}$ and vitamin $B_{2}$ contents in natural yoghurts, liquid yoghurts and Petit Suisse significantly decrease as the date increases. This decrease takes place at all the dates.

Natural yoghurts show significant differences in vitamin $B_{1}$ contents depending on the samples and on the dates of analysis. The same result occurs in liquid yoghurts and in Petit Suisse.

Vitamin $B_{1}$ contents in liquid yoghurts are very similar to those in Petit Suisse, and lower than those in natural yoghurts. However, vitamin $B_{2}$ follows the relationship: natural yoghurts > liquid yoghurts > Petit Suisse.

\section{REFERENCES}

Association of Official Analytical Chemists (1990) Official Methods of Analysis. William Byrd Press Inc, Richmond

Favier JC (1987) Composition du yaourt. Cah Nutr Diet 5, 373-379

Souci SW, Fachmann W, Krant H (1986/1987) Food Composition and Nutrition Tables. Wissenschaftliche Verlagsgesellschaft, Stuttgart 